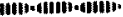

Note

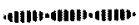

(Received September 17, 1985)

\title{
PHOTO-INDUCED FORMATION OF $\alpha$-HELICAL STRUCTURE OF POLY(L-GLUTAMIC ACID) CONTAINING PARAROSEANILINE IN THE SIDE CHAINS
}

\author{
By Morimasa Sato, Takatoshi Kinoshita, Akira Takizawa \\ and Yoshiharu Tsujita \\ (Nagoya Institute of Technology, Gokiso-cho, Showa-ku, Nagoya 466)
}

\section{SUMMARY}

A photoresponsive polypeptide has been prepared by condensation reaction of poly(L-glutamic acid) (PGA) with pararoseaniline (Rose) in dimethylformamide solution (Rose-modified PGA). The Rose side chains in the polymer exhibited the photo-ionization under uv light irradiation, yielding triphenylmethyl cations, which vanished completely in the dark. The helix content of Rose-modified PGA, $4.3 \%$ in the dark, was increased to $7.2 \%$ by uv light irradiation at $\mathrm{pH} 9.7$, owing to the compensation for carboxylate anion (glutamic acid side chain) repulsions resulting from the production of the triphenylmethyl cation on the polymer chains by uv irradiation. The photo-induced changes of the conformation of Rose-modified PGA at $\mathrm{pH} 9.7$ were reversible and in correlation with the change in absorbance at $560 \mathrm{~nm}$ of Rose side chain groups. On the other hand, the Rose side chains in the polymer exhibited no photo-ionization under uv light at $\mathrm{pH} 5.7$, owing to the neutralization effect in the low $\mathrm{pH}$ aqueous solution. As a result, uv irradiation did not induce any variations in conformation of Rose-modified PGA at pH 5.7.

\section{INTRODUCTION}

The photochromic dyes, which are covalently or non-covalently connected to polymers, have been used to control polymer conformation and to regulate photochemically the membrane functions. ${ }^{1-4)}$ We have already shown that the membrane functions of poly(L-glutamic acid) containing azobenzene side chains, such as membrane potentials and transport properties, can be controlled by light irradiation. ${ }^{5)-7)}$

Triphenyl methane leuco derivatives are wellknown photochromic dyes, which dissociate into ion pairs under light irradiation with production of the corresponding dyes. Irie et al. $^{8)}$ have shown the photo-induced conformational changes of vinyl polymers caused by a charge density change of the polymer resulting from the photoisomerization of photochromic side chains.

In this paper, using poly(L-glutamic acid) with a triphenyl methane leuco derivative, pararoseaniline, in the side chains, we report on the photo-induced formation of $\alpha$-helical structure of the polymer by light irradiation via the compensation effect for glutamic acid side chain repulsions resulting from the photo-induced production of triphenylmethyl cations on the polymer chains.

\section{EXPERIMENTAL}

\section{Materials}

Poly(L-glutamic acid) (PGA, 1.0g, $\bar{M}_{v}=1.19$ $\left.\times 10^{5}\right)$ was dissolved in dimethylformamide (DMF, 50cc). Pararoseaniline (Rose, $0.68 \mathrm{~g}$ ), N-hydroxybenzotriazole (HOBT, 0.32g) and dicyclohexylcarbodiimide (DCCI, 0.48g) were added to the stirred mixture at $0^{\circ} \mathrm{C}$. After $24 \mathrm{~h}$ at room temperature, the bulk of the DMF solution was filtrated and the polymer was obtained by precipitation with methanol. Any unreacted Rose reagent was removed by extraction. The obtained PGA with Rose in the side chains (Rose-modified PGA) was dissolved in alkaline aqueous solution $(8.7$ $\times 10^{-4} \mathrm{~g} / \mathrm{cc}$ ) for UV and CD measurements. The Rose content determined on the basis of the molar 
extinction coefficient of the triphenylmethyl cation $\left(\lambda_{\max }=540 \mathrm{~nm}\right.$, in $\mathrm{pH} 5.7$ water $)$ was ca. $1.1 \mathrm{~mol} \%$.

\section{Measurements}

Absorption spectra and $C D$ spectra of the solution were measured with a spectrophotometer (Shimadzu Co. Ltd. UV-200) and a spectropolarimeter (Jasco J-40), respectively, $\mathrm{pH}$ of the solution was measured by a $\mathrm{pH}$ meter (Horiba $\mathrm{pH}$ meter F7-ss). All the measurements were carried out at $\mathrm{pH} 9.7,8.5,5.7$, respectively, at $25^{\circ} \mathrm{C}$.

Irradiation was carried out with a $500 \mathrm{~W}$ superhigh-pressure mercury lamp (Ushio USH-500D) and the irradiation wave length was limited to the ultraviolet region using glass filter (Toshiba UVD33S).

\section{RESULTS AND DISCUSSION}

\section{Photo-isomerization}

Rose dissociates into ion pairs under uv irradiation, yielding the colored triphenylmethyl cations, and the cations thermally recombine with counterions, as shown in Eq(1). This was confirmed by

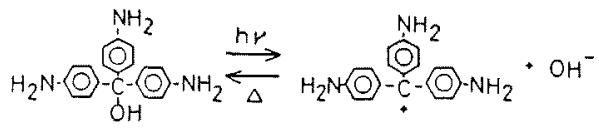

the UV spectra resulting from the change in the absorption band at 540 nm in Figure 1.

The Photo-isomerization (Photo-ionization) of Rose-modified PGA was also evaluated by UV

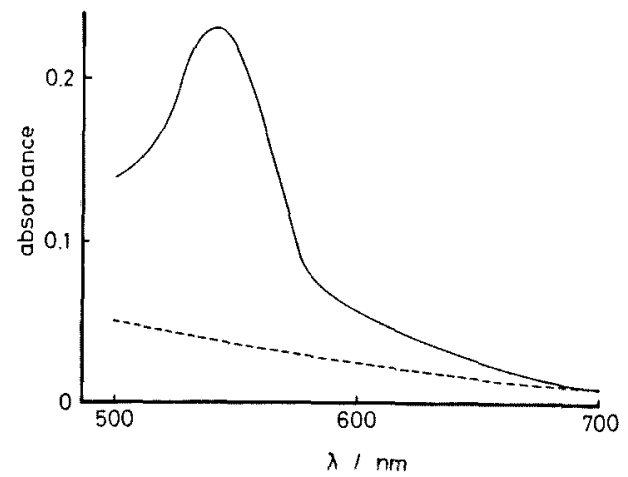

Fig. 1 Absorption spectra of pararoseaniline (1.04 $\times 10^{-5} \mathrm{~mol} \cdot \mathrm{dm}^{-3}$ ) in aqueous solution of $\mathrm{pH} 9.5$ containing distearyl-dimethylammonium chloride $\left(1.67 \times 10^{-3} \mathrm{~mol} \cdot \mathrm{dm}^{-3}\right)$ at $25^{\circ} \mathrm{C}(-\ldots \ldots)$ in the dark, —__ : after uv irradiation). spectra. Figure 2 shows that UV spectra of Rosemodified PGA solution at $\mathrm{pH}$ 9.7. Before up irradiation, no remarkable absorption bands between $700 \mathrm{~nm}$ to $500 \mathrm{~nm}$ were existence, but after uv irradiation the absorption band resulting from the triphenylmethyl cation appeared at $560 \mathrm{~nm}$. At lower $\mathrm{pH}$, however, the ionization has already occurred without uv irradiation, which is owing to the neutralization effect in low $\mathrm{pH}$ aqueous solution (Figure 3). The $\mathrm{pKa}$ value of pararoseaniline was shown to be $7.6 .^{9)}$ uv irradiation, therefore, did not induce any photo-ionization of Rose side chains at $\mathrm{pH} 5.7$. Thus the ionization of side chain Rose moieties of Rose-modified PGA can be controlled by uv light at higher $\mathrm{pH}$ region.

\section{Photo-induced formation of $\alpha$-helical structure of Rose-modified PGA}

The conformational changes of Rose-modified PGA upon uv irradiation were evaluated by $C D$ measurement. Figure 4 shows the $\mathrm{CD}$ spectra of

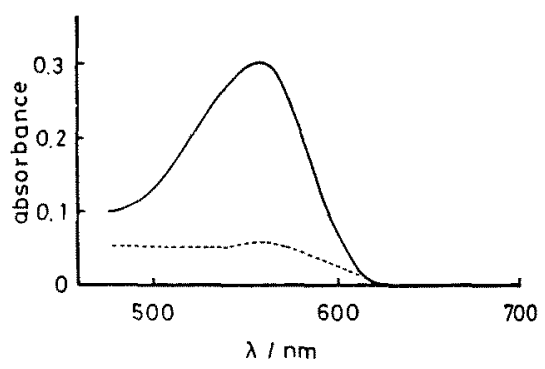

Fig. 2 Absorption spectra of the Rose-modified PGA in aqueous solution of $\mathrm{pH} 9.7$ at $25^{\circ} \mathrm{C}$ (--_- : in the dark, - after uv irradiation).

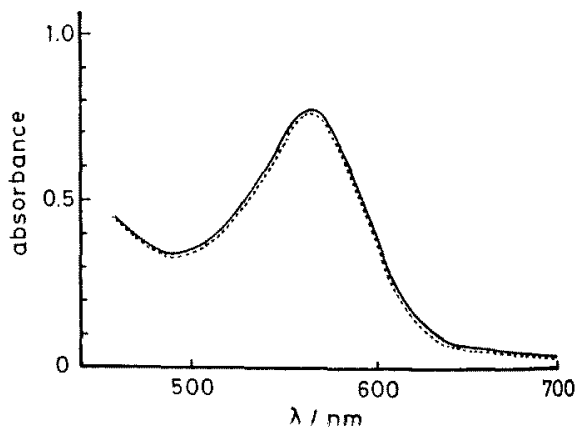

Fig. 3 Absorption spectra of the Rose-modified PGA in aqueous solution of $\mathrm{pH} 5.7$ at $25^{\circ} \mathrm{C}$ (-.-.): in the dark, __ : after uv irradiation). 
(a)

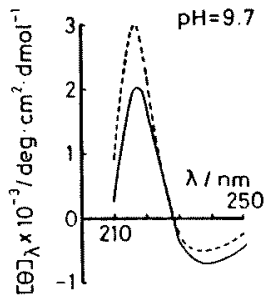

(b)

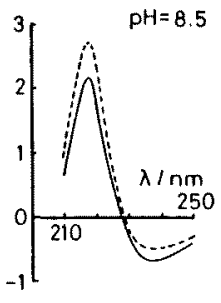

(c)

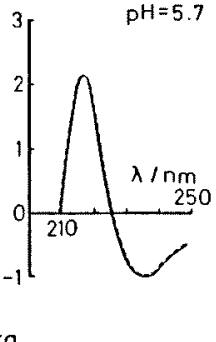

Fig. 4 CD spectra of the Rose-modified PGA before (-..--) and after $(-)$ irradiation in aqueous solution of $\mathrm{pH} 9.7 ;(\mathrm{a}), 8.5$; (b), 5.7; (c) at $25^{\circ} \mathrm{C}$.

Rose-modified PGA at various $\mathrm{pH}$. $\mathrm{CD}$ measurement of the Rose-modified PGA could not be carried out below $200 \mathrm{~nm}$, since excess noise is produced in their CD spectra. The random coil state of poly ( $\alpha$-amino acid) is generally characterized by the negative band at $197 \mathrm{~nm}\left([\theta]_{197}=\right.$ $\left.-41,9 \times 10^{3}\right)$ and positive band at $217 \mathrm{~nm}\left([\theta]_{217}\right.$ $=4.6 \times 10^{3}$ ) in the CD spectra. The positive values of the molar ellipticity, $[\theta]_{217}$, of the Rosemodified PGA in the dark (dashed curves in Figure 4), $3.00 \times 10^{3} \mathrm{deg} \cdot \mathrm{cm}^{2} \cdot \mathrm{dmol}^{-1}(\mathrm{pH} 9.7)$, $2.70 \times 10^{3}(\mathrm{pH} 8.5)$ and $2.10 \times 10^{3}(\mathrm{pH} \mathrm{5.7)}$, indicate that the polymer is in random coil rich structure. Greenfield et al. ${ }^{10}$ ) have shown the calculated $C D$ curves which were obtained by theoretical combinations of $\alpha$-helix and random forms poly(L-lysine in aqueous solution. The best fit of the experiment CD curves of Rose-modified PGA with calculated one from $210-240 \mathrm{~nm}$, which is proposed by Greenfield et al., gives a helical content of $4.3 \%(\mathrm{pH} \mathrm{9.7)}, 5.2 \%(\mathrm{pH} 8.5)$ and $6.9 \%$ $(\mathrm{pH} 5.7)$, respectively. Similar procedure was applied to CD spectra after uv irradiation (solid curves in Figure 4), and gives a helical content of $7.2 \%(\mathrm{pH} 9.7)$ and $6.5 \%(\mathrm{pH} 8.5)$, respectively. That is, the formation of $\alpha$-helical structure of the polymer was induced by uv irradiation at high $\mathrm{pH}$ region. It is noticeable that the degree of photo-induced increase in the helix content at $\mathrm{pH} \mathrm{9.7,} \mathrm{ca.} \mathrm{67 \% ,} \mathrm{is} \mathrm{larger} \mathrm{than} \mathrm{that} \mathrm{at} \mathrm{pH} 8.5$, ca. $25 \%$. As described above, Rose side chains are converted to the dye cations, yielding the free hydroxide anion by uv irradiation. Both ions have an opposite effect on the conformation of PGA polymer, i.e., the dye cations produce positive fixed charges on the polymer chains among the negative charges of glutamic acid. On the other hand, the free hydroxide anions increase the degree of dissociation of the glutamic acid side chains. The former effect may result in the stabilization of the $\alpha$-helix conformation of Rosemodified PGA owing to reduction of carboxylate anion repulsions, and the latter increases the anion-anion repulsions between glutamic acid side chains. At pH 9.7, the carboxylate anions of the Rose-modified PGA are fully ionized. Therefore, the former effect may be predominate at this $\mathrm{pH}$. So that the photo-induced formation of $\alpha$-helix structure of Rose-modified PGA at pH 9.7 can be explained in terms of the former effect, i.e., the compensation for carboxylate anion repulsions resulting from the production of the triphenylmethyl cations on the polymer chains by uv irradiation. On the other hand, the degree of ionization of the Rose-modified PGA side chains, carboxylate anions, at $\mathrm{pH} 8.5$ is relatively lower than that at $\mathrm{pH} 9.7$. Therefore, the effect of the yielding the free hydroxide anion on the conformation of the Rose-modified PGA (latter effect) may not be negligible at $\mathrm{pH} 8.5$, i.e., the former effect which results in the stabilization of the $\alpha$-helix structure is reduced by the latter. This is the reason why the degree of the photo-induced increase in the helix content of the polymer at $\mathrm{pH} 8.5$ is lower than that at $\mathrm{pH} 9.7$. At lower $\mathrm{pH}(\mathrm{pH} 5.7)$ the value of $[\theta]_{217}$ was independent of uv irradiation (Figure $4(\mathrm{c})$ ), i.e., the conformation of Rose-modified PGA was unchanged by uv irradiation at lower $\mathrm{pH}$. This result is consistent with the fact that uv irradiation did not induce 


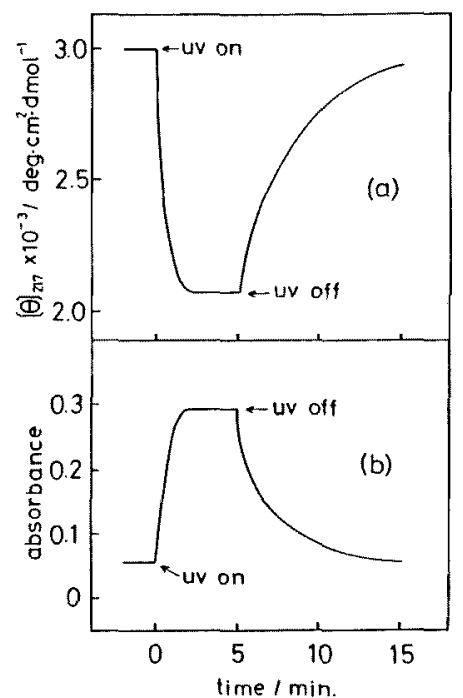

Fig. 5 (a) Photo-induced changes in molar ellipticity, $[\theta]_{217}$, of the Rose-modified $\mathrm{PGA}$ in aqueous solution of $\mathrm{pH} 9.7$ at $25^{\circ} \mathrm{C}$.

(b) Photo-induced changes in absorbance at $560 \mathrm{~nm}$ of the Rose-modified PGA in aqueous solution of $\mathrm{pH} 9.7$ at $25^{\circ} \mathrm{C}$.

any variations in ionization state of Rose side chains of PGA polymer as shown in Figure 3.

Figure 5(a) shows the decrease and recovery cycles of the value of $[\theta]_{217}$ of Rose-modified PGA solution at $\mathrm{pH} 9.7$. The photo-induced changes of the value of $[\theta]_{217}$ are almost consistent with the absorption changes at $560 \mathrm{~nm}$ of
Rose-modified PGA solution at $\mathrm{pH}$ 9.7. This result also suggests that the photo-induced formation of $\alpha$-helix structure of Rose-modified PGA can be attributed to the ionization reaction of Rose side chains upon uv irradiation at higher $\mathrm{pH}$ region.

\section{ACKNOWLEDGMENT}

The authors gratefully acknowledge the support of the Japanese Ministry of Education through a Grant-in-Aid for Developmental Science Research (No. 60750822).

\section{REFERENCES}

1) A. Ueno, J. Anzai and T. Osa, J. Polym. Sci, Polym. Lett. Ed., 15, 407 (1977).

2) M. Irie, Y. Hirano, S. Hashimoto and K. Hayashi, Macromolecules, 14, 262 (1981).

3) S. Kato, M. Aizawa and S. Suzuki, J. Membr. Sci., 2, 39 (1977).

4) K. Ishihara and I. Shinohara, J. Polym. Sci. Polym. Lett. Ed., 22, 515 (1984).

5) A. Takizawa, M. Sato, T. Kinoshita and Y. Tsujita, Chem. Lett, 1984, 1963.

6) T. Kinoshita, M. Sato, A. Takizawa and Y. Tsujita, J, Chem. Soc., Chem. Commun. 1984, 929.

7) T. Kinoshita, M. Sato, A. Takizawa and Y. Tsujita, Macromolecules, in press.

8) M. Irie and D. Kungwatchakun, Makromol Chem., Rapid Commun., 5, 829 (1985).

9) R. J. Goldacre and J. N. Phillips, J. Chem. Soc., 1949, 1724.

10) N. Greenfield and G. D. Fasman, Biochemistry, 8, 4108 (1969).

\section{パラローズアニリンを側鎖に有するポリ（Lーグルタミン酸） \\ の光照射による $\alpha$-ヘリックス構造の形成}

\section{名古屋工業大学传藤守正，木下隆利，滝沢章，辻田義治}

側鎖にトリフェールメタン系染料の一䅜であるパラロ ーズアニリン構造存するポリ（上ーグルタミン酸）(RosePGA)を合成し，UV照射飞基つくこのポリマ一の二次 構浩変化老解析した。 $\mathrm{pH}=9.7$ 水溶液に招いてRosePGAは、ランダムコイル棰造をとるがUV照射により一 部风ーヘリックス棈造が形成されるととがわかった。また 同采 $0 \mathrm{pH}=5.7$ で同樣な測定老行なったが，二次構诰に は何ら変化珄じなかった。方 $\mathrm{pH}=9.7$ の水溶液に戈 けるUV測定の結果，パラローズアニリン側銷はUV照
射により光異性化しトリフェニルメタンカチオンを生成

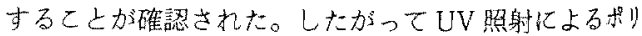
マーの三次構造変化は則鎖パラローズアニリンの光異性 化に基ついていることが裹付けられた。つまりUV照射 に伴い側鎖パラローズアニリンが光翼性化(トリフェニル メタンカチオン生成)し，グルタミン酸側銷間の負電荷間 の反発を㧕制し， $\alpha$ ーヘリックス構造加安定化されると結 諭づけられた。 